R O C ZNIKI HUMAN IS T Y C Z N E

Tom LXVIII, zeszyt 5 - 2020

ZESZYT SPECJALNY / SPECIALE UITGAVE

DOI: http://dx.doi.org/10.18290/rh20685sp-10

KATARZYNA WIERCIŃSKA

\title{
WIE ZIJN ER NU TOLERANTER? \\ DE PERCEPTIE VAN IMPERATIEVEN IN HET POOLS EN HET NEDERLANDS IN EEN INFORMELE CONTEXT
}

\begin{abstract}
A b stract. Het doel van deze bijdrage is een antwoord te vinden op de vraag of intransitieve werkwoorden met voorzetselvoorwerpen gepassiveerd kunnen worden. Om dit antwoord te kunnen geven, wordt eerst het voorzetselvoorwerp gepresenteerd en een korte beschrijving van het Nederlandse passief gegeven.
\end{abstract}

Trefwoorden: imperatief; beleefdheidsstandaarden; perceptie; Pools; Nederlands.

\section{INLEIDING}

"Hey, Alexa, start een timer!", zei de ICT’er Maarten Lens-FitzGerald tegen de voice assistant van Amazon terwijl hij een nieuw commando demonstreerde voor een publiek van techniekliefhebbers ("De Technoloog: Smart speakers zijn smart listeners", 9.05.2018). Tot zijn verbazing kreeg hij van zijn toeschouwers geen feedback op de werking van het systeem, maar op de formulering van zijn commando. Feedback op zijn taalgebruik: "Waarom ben je zo onaardig tegen Alexa?". De reden is dat computers compacte commando's beter verstaan en begrijpen. Een voice assistant is immers geen levend mens die gevoelens en een onafhankelijk begripsvermogen heeft. Deze situatie laat goed zien hoe gevoelig het kan liggen om imperatieven te gebruiken. Aan de ene kant is de gebiedende wijs een effectief communicatiemiddel door de compacte vorm. Aan de andere kant lijkt het alsof taalge-

Dr. KatARZYNa WierciŃSKa is Universitair Hoofddocent (Adiunkt) bij de Vakgroep Nederlandse en Zuid-Afrikaanse Studies van de Uniwersytet A. Mickiewicza in Poznań. Correspondentieadres: Zakład Studiów Niderlandzkich i Południowoafrykańskich, Wydział Anglistyki, Uniwersytet im. A. Mickiewicza, al. Niepodległości 4, 61-874 Poznań; e-mail: kwiercinska@wa.amu.edu.pl. ORCID: https://orcid.org/0000-0001-7341-3138. 
bruikers het belangrijker vinden om aardig $^{1}$ gevonden te worden dan hun boodschap zo efficiënt mogelijk te communiceren. Dit leidt ertoe dat veel mensen zelfs een computer op een vriendelijke toon willen aanspreken. Sorjonen et al. (1) verklaren dit fenomeen als volgt: imperatieven buiten ouder-kindrelaties worden meestal aangevoeld als vormen die een "intrinsieke dosis" van onbeleefdheid bevatten.

Deze bijdrage richt zich op de perceptie van imperatieven in spontane gesprekken van Poolse en Nederlandse moedertaalsprekers en bespreekt de resultaten van een pilot-enquête naar beleefdheidsstandaarden. ${ }^{2}$ De deelnemers beoordelen een aantal zinnen met imperatieve constructies uit corpora gesproken Nederlands en Pools op beleefdheid. Vervolgens krijgen ze de opdracht om de zinnen te classificeren als een bepaald type taalhandeling: is het een bevel, een eis, een opdracht, een verzoek, een suggestie of misschien een hint? De context van de gekozen zinnen beperkt zich tot gesprekken in informele situaties tussen sprekers die een (vrij) nauwe relatie met elkaar hebben (bijv. familieleden, partners of vrienden).

De Poolse cultuur is collectiever en hiërarchischer ingesteld dan de $\mathrm{Ne}$ derlandse (Hofstede). ${ }^{3}$ Een samenleving waar de hiërarchie duidelijker is en waar de nadruk ligt op de gemeenschap en niet op het individu, is volgens Zinken en Ogiermann ("Responsibility and Action" 275) en Sorjonen et al. (1) meer bereid om directere boodschappen te accepteren. Uit de geanalyseerde verzameling corpusgesprekken ${ }^{4}$ blijkt dat imperatieven in het Pools en Nederlands kwalitatief en kwantitatief inderdaad anders worden gebruikt. Van alle directieven in deze corpusgesprekken ( 100.000 woorden per taal) is

\footnotetext{
${ }^{1}$ De Nederlandstalige Alexa bestaat ook in een versie voor kinderen waarin ze aan elk commando 'alsjeblieft' en 'dankjewel' moeten toevoegen. Dit is interessant vanuit een taalkundig perspectief. De makers (en ouders) waren namelijk bang dat kinderen deze directe vormen ook in de reële wereld zouden gaan gebruiken. De bedoeling is dus om hier 'de netheid' van communicatie te garanderen. ("De Technoloog...", 9.05.2018).

${ }^{2}$ In deze bijdrage worden alleen imperatieven besproken. Het pilotonderzoek omvat echter ook andere vormen zoals bijv. vraagvormen, statements van noodzakelijkheid ('Je moet...') en onpersoonlijke constructies (Wiercińska, "Op zoek").

${ }^{3}$ Wat betreft machtsafstand en collectivisme/individualisme, is er een vrij groot verschil tussen Polen en Nederland: PDI Polen: 68, Nederland: 38; IDV Polen: 60, Nederland: 80 (Hofstede). PDI (Power Distance Index) staat voor machtsafstand die te maken heeft met sociale ongelijkheid en hiërarchie. Hoe hoger de score, hoe hiërarchischer de samenleving in kwestie is. IDV (Individualism) bepaalt wie van groter belang is: een individu of de hele groep. Hoe hoger de score, hoe meer nadruk ligt op een individu en niet op collectief handelen.

${ }^{4}$ De geanalyseerde gesprekken komen in beide talen met elkaar overeen wat betreft de omstandigheden waarin het gesprek plaatsvindt en het soort relatie tussen de sprekers. De gebruikte corpora zijn het Corpus Gesproken Nederlands en Spokes (een corpus van gesproken informeel Pools).
} 
in het Pools $83 \%$ een imperatief tegen slechts $26 \%$ in het Nederlands. ${ }^{5}$ De Polen gebruiken daarbij vooral kale ${ }^{6}$ en versterkte imperatieven. De Nederlanders geven daarentegen de voorkeur aan verzachte imperatieven (Wiercińska, "Op zoek" 173). Hoe vaak een vorm voorkomt, kan iets zeggen over hoe acceptabel hij is. Op basis van het kwantitatieve en kwalitatieve gebruik van imperatieven in beide talen en de sociale factoren zoals machtsafstand en collectivisme/individualisme, kunnen we de volgende hypotheses formuleren:

- Polen staan over het algemeen toleranter tegenover imperatieven dan Nederlanders.

- De versterkte of verzachte vorm heeft meer invloed op de acceptatie van de imperatief in Nederland dan in Polen.

- Polen ervaren imperatieven als minder dwingend.

\section{DE PERCEPTIE VAN DIRECTIEF TAALGEBRUIK: EEN PAAR OVERWEGINGEN}

Vanuit het perspectief van de ontvanger van de boodschap hangt een directieve taalhandeling samen met een mogelijke dreiging voor zijn persoonlijke autonomie. Hij voelt zich immers in meer of mindere mate gedwongen om tijd, moeite of andere middelen (zoals geld of objecten die hij bezit) aan de ander te besteden zodat die daar voordeel voor zichzelf uithaalt (Brown en Levinson 65-66). Hoeveel druk er achter elke directieve taalhandeling staat, ervaart de ontvanger subjectief, wat niet alleen afhangt van de context (Ochs 10, Lubecka 58, Lee 395), maar ook van culturele factoren (zoals de sociale structuur van de gegeven maatschappij, Chen et al. 141-142, Rossi 103-104). De verbanden tussen de taalhandeling en hoe de taalgebruiker het ervaart, kunnen we dan op de volgende manier schematisch weergeven (Figuur 1).

\footnotetext{
${ }^{5}$ Uit een vergelijking van de studies van Bolden en Mandelbaum, die een onderzoek hebben gedaan naar het taalgedrag in gesprekken onder het eten in de Verenigde Staten en in Rusland, blijkt dat er een vergelijkbaar verschil is. In het onderzochte Amerikaanse gezin was 19\% van de directieven een imperatief tegen $90 \%$ in het Russische gezin.

${ }^{6}$ Een kale imperatief is een vorm die alleen beperkt is tot de boodschap. Het bevat geen elementen die de boodschap sterker of zachter kunnen maken. Een vorm kan op twee manieren versterkt of verzacht worden. Op taalniveau gebeurt het met behulp van bijv. modale partikels, diminutieven enz. Op logisch niveau wordt een vorm versterkt of verzacht door te wijzen bijv. op een voordeel of mogelijk negatief gevolg.
} 


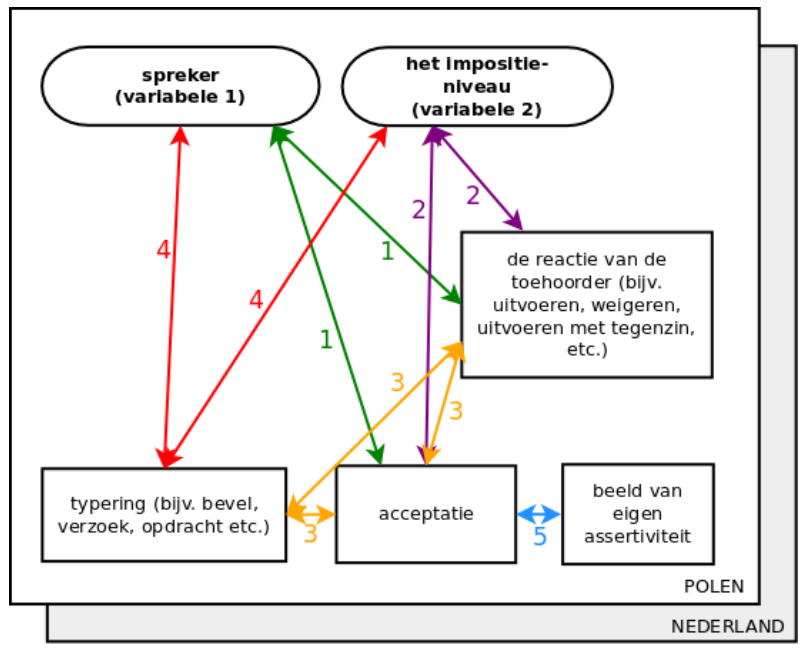

Figuur 1. De verbanden tussen de taalhandeling en de context.

De sociale context van elke directieve taalhandeling bestaat uit drie onderdelen: de sociale afstand ( $\mathrm{D}$, distance), macht ( $\mathrm{P}$, power) die de ene spreker kan uitoefenen op de andere en de mogelijke dreiging voor de persoonlijke autonomie van de ontvanger ( $\mathrm{R}$, risk). Hoe meer moeite de ontvanger moet doen, hoe groter de dreiging van dit verzoek is (Brown en Levinson 2011; Brown en Gilman 1982).

De verbanden tussen de perceptie van de taalhandeling en de bovengenoemde onderdelen van de context zien er als volgt uit. Hoe nauwer de relatie is tussen de sprekers (verband 1 van Figuur 1.), hoe groter de kans dat de ontvanger de taalhandeling aanvaardbaar vindt en de actie zal uitvoeren. Hoe meer moeite de ontvanger moet doen om de gevraagde handeling uit te voeren (verband 2), des te minder kans dat hij het aanvaardbaar vindt. Hoe negatiever de ontvanger de taalhandeling vindt, hoe minder kans dat hij hem uitvoert. De mate van acceptatie van een taalhandeling bepaalt hoe de ontvanger hem zou benoemen (bijv. een bevel, een verzoek of een suggestie) (verband 3). De taalhandeling wordt als dwingender ervaren naarmate de sociale afstand tussen de sprekers groter wordt (verband 4). Uiteindelijk is er nog een persoonlijke factor die meespeelt bij de perceptie, namelijk het beeld van de eigen assertiviteit van de ontvanger (verband 5). Hoe assertiever de ontvanger zichzelf vindt, hoe minder kans dat hij positief reageert op (vooral dwingende) directieven. 


\section{DE PERCEPTIE VAN IMPERATIEVEN: REEDS BESTAAND ONDERZOEK}

Hoewel directieve taalhandelingen tot de meest onderzochte taalhandelingen behoren (cf. Ogiermann 40, Chen et al. 140), komt de perceptie ervan niet zo vaak aan bod als hun andere aspecten, zoals bijvoorbeeld aan welke vorm taalgebruikers voorkeur geven in verschillende talen. Zoals al in de inleiding vermeld, wordt vaak aangenomen dat de imperatieven per definitie tot minder beleefde taalvormen behoren (Sorjonen et al. 1). Deze opvatting komt voort uit het specifieke karakter van imperatieven. De boodschap is kort en bondig zodat het direct duidelijk is wat we van onze gesprekspartner vragen. In dat geval zorgt de vorm ervoor dat de illocutieve kracht van zo'n taalhandeling wordt versterkt en als (vrij) dwingend kan overkomen. Vanuit syntactisch perspectief wordt de imperatief immers gezien als "een prototypische vorm van een bevel" (Vismans 17).

De vakliteratuur kijkt tegenwoordig vanuit twee verschillende perspectieven naar de perceptie van imperatieven. Het eerste perspectief is cultuurgebonden en in het tweede perspectief komen imperatieven voort uit een communicatieve situatie, zonder een link te leggen met de cultuur. Het reeds bestaande onderzoek maakt gebruik vooral van twee methodes: observaties van (taal)gedrag (bv. Zinken en Ogiermann; Rossi; Mondada; Zinken en Depperman) of een invulopdracht, de zogenoemde discours completion test ${ }^{7}$ (verder afgekort als DCT; Van Mulken; Lubecka; Ogiermann). Veel minder wordt gewerkt met enquêtes waarin zinnen beoordeeld worden op beleefdheid (Vismans).

In de Poolse en Nederlandse taalkunde wordt niet veel aandacht besteed aan de perceptie van directieven. We kunnen ons ook vragen stellen bij de gebruikte methodes en het onderzoeksmateriaal. Ogiermann (29-30) schrijft dat in het onderzoek naar de Poolse taal twijfels kunnen ontstaan over de

\footnotetext{
${ }^{7}$ Een aandachtspunt hier is echter dat er vrij grote verschillen kunnen optreden tussen de taalhandelingen die de onderzochte taalgebruikers werkelijk zouden produceren in de face-to-face communicatie en het materiaal verzameld met behulp van DCT (zie Ogiermann 69; Cyluk 105). Het door DCT verzamelde taalmateriaal mist spontaniteit in die zin dat de taalhandelingen enigszins doordacht zijn voordat de deelnemer ze opschrijft. Als de taalhandeling een directe reactie is op de woorden van de zender, is het veel minder waarschijnlijk dat de ander überhaupt kan nadenken over de vorm van zijn reactie. Daarom is het de vraag of het op deze manier verzamelde taalmateriaal een $100 \%$ betrouwbaar inzicht geeft in de specificiteit van communicatie in een bepaalde taal in een bepaalde situatie. We zouden de resultaten van DCT echter kunnen zien als een indicatie van de gewenste beleefdheidsstandaarden in een bepaalde cultuur. Beebe en Cummings (75) gaan ervan uit dat de deelnemer aan de studie, die zich laat leiden door specifieke normen en waarden in zijn communicatie met anderen, hoogstwaarschijnlijk een taalhandeling opschrijft die hij graag zelf zou willen zeggen in een bepaalde situatie en niet wat hij in de praktijk zou zeggen.
} 
keuze van het onderzoeksmateriaal en de manier waarop het wordt geïnterpreteerd. De onderzoekers maken gebruik van pers- of literatuurteksten (bv. Pisarek; Marcjanik, "Precision") en in hun interpretatie berusten ze eerder op hun individuele taalgevoel (bijv. Wierzbicka; Marcjanik, "Precision"). Lubecka, Ogiermann en Zinken en Ogiermann onderzoeken daarentegen hoe culturele waarden het syntactische, lexicale en pragmatische niveau van imperatieven beïnvloeden. De huidige staat van onderzoek naar de Nederlandse taal is redelijk vergelijkbaar. Tot dusverre heeft het onderzoek zich primair gericht op welke vorm het vaakst gebruikt wordt (Van Mulken) of op het gebruik van modale partikels in directieven (Vismans). Vismans maakt daarbij een korte enquête waarin hij deelnemers een paar directieven in dezelfde situatie (de deur sluiten) laat beoordelen op beleefdheid. De directieven zijn alleen in één beperkte context geplaatst (mensen van min of meer dezelfde leeftijd die elkaar niet kennen) en worden beoordeeld door 24 deelnemers. Imperatieven scoren het laagst en conditionele vraagvormen het hoogst op beleefdheid.

\subsection{De CultuUrgebonden perceptie Van imperatieven}

Van der Wijst (477-478) concludeert dat zelfs kleine stilistische verschillen in de vorm van taalhandelingen in verschillende talen tot misverstanden kunnen leiden en op deze manier de effectieve communicatie verstoren, vooral met betrekking tot 'beleefdheidsgevoelige' directieven. Ondanks het feit dat de boodschap op lexicaal en grammaticaal niveau helemaal correct is, loopt de taalgebruiker altijd het risico dat hij vaak de vormen kiest die natuurlijk voelen in zijn moedertaal als hij een vreemde taal spreekt. Dit is een mogelijke verklaring voor de ophef die in 2012 ontstond rond Polen in Groot-Brittannië. De Britse kranten berichtten dat de Poolse beleefdheid "verloren gaat in de vertaling" (Doughty). Aangezien imperatieven in het Pools heel vaak gebruikt worden, gebruiken Polen ze op dezelfde manier als ze Engels spreken. Deze manier van communiceren was echter niet acceptabel voor de Britten die zelf vragende vormen zouden gebruiken. Ook Lubecka (9) signaleert dit soort potentiële misverstanden met een interculturele achtergrond en ze schrijft dat het tegenwoordig heel makkelijk is om de geografische grenzen te overschrijden, maar het respecteren van de culturele grenzen is niet zo vanzelfsprekend. Zowel Van der Wijst (479) als Lubecka (259) benadrukken dat het gaat om verschillende communicatieverwachtingen van individuele gemeenschappen, die bijvoorbeeld het gevolg kunnen zijn van andere opvattingen over hiërarchie. 
Zinken en Ogiermann (275) wijzen erop dat imperatieven makkelijker worden geaccepteerd door samenlevingen waar de sociale hiërarchie duidelijker is en waar de gemeenschap belangrijker is dan het individu. Marcjanik (238) schrijft dat "de traditionele Poolse beleefdheid hiërarchisch is, wat in contrast staat met egalitarisme en de hype van individualisme." Łaziński (18) sluit zich daar ook bij aan en schrijft dat "een sterke neiging om collectief te handelen" belangrijk is in de Poolse hiërarchie wat volgens hem ook leidt tot een grotere acceptatie van directe vormen. Imperatieven hoeven echter niet per se te maken te hebben met maatschappelijke hiërarchie. Wierzbicka (150-160) stelt bijvoorbeeld dat zo'n communicatiestijl te maken kan hebben met positieve waarden, zoals spontaniteit en een positieve houding ten opzichte van onze gesprekspartner. De illocutieve kracht van elke imperatief kan bovendien altijd verzacht worden, bijvoorbeeld door diminutieven te gebruiken.

Het lijkt er dus op dat collectief ingestelde samenlevingen vooral naar de effectiviteit van de boodschap kijken, aangezien een effectief uitgevoerde handeling een voordeel oplevert voor alle betrokken partijen. Ook zorgt de hiërarchie ervoor dat interpersoonlijke verhoudingen vaststaan waardoor ze niet continu herbevestigd moeten worden met allerlei beleefdheidsformules. Tot nu toe is er weliswaar nog geen onderzoek uitgevoerd naar communicatieve verwachtingen van Polen, maar deze conclusie komt terug in onderzoeken naar andere talen waarvan de sprekers in een hiërarchische en collectieve cultuur leven. Uit een analyse van het imperatiefgebruik in het Chinees ${ }^{8}$ (Lee-Wong) blijkt dat de korte vorm vooral wordt geassocieerd met efficiëntie. Daarom worden imperatieven daar niet als onbeleefd gezien. Chen et al. (141-142) maken een vergelijkbare veronderstelling in hun studie naar beleefdheidsstandaarden in het Japans en Chinees. Directe vormen zien ze als een weerspiegeling van het Chinese collectivisme. Indirecte vormen waarmee de spreker de persoonlijke vrijheid van zijn gesprekspartner kan respecteren, werken in hun ogen niet echt in China. Het gebrek aan autonomie van het individu in de Chinese cultuur zou een reden kunnen zijn waarom Chinezen geen moeite willen doen om indirect hun wensen te formuleren, in tegenstelling tot bijvoorbeeld Engelsen. Bolden (176) trekt een vergelijkbare conclusie in haar onderzoek naar de imperatieven in het Russisch. ${ }^{9}$ Vooral bij

\footnotetext{
${ }^{8}$ Wat betreft de machtsafstand en collectivisme/individualisme, scoort China heel hoog op PDI: 80, en laag op IDV: 20 (Hofstede).

${ }^{9}$ Ook Ogierrnann komt op basis van een DCT tot een vergelijkbare conclusie. De resultaten van haar onderzoek naar de voorkeursvormen in het Engels, Duits, Pools en Russisch suggereren dat hoe oostelijker een land ligt, hoe meer directe vormen er worden gebruikt. Chen et al. (140-
} 
handelingen die niet veel inzet vragen, vermoedt zij dat beleefdheid hier überhaupt niet van belang is.

De Nederlandse deelnemers aan de pilotstudie associëren imperatieven echter niet met effectiviteit. In de commentaren die zij hebben geleverd op de enquête, noemden ze imperatieven bijvoorbeeld "geruis op de lijn" of "gebrek aan olie in het communicatiemechanisme". Een invulopdracht van Van Mulken (694) laat zien dat de deelnemers directe vormen liever vermijden ( $71 \%$ van de reacties op de onderzochte situaties waren vraagvormen). Een kleine perceptiestudie uitgevoerd door Vismans (206-210) onder een groep van 24 respondenten toont aan dat imperatieven inderdaad als het minst beleefd beoordeeld werden. Deze resultaten komen op zich overeen met de specificiteit van de Nederlandse cultuur die hoog op individualisme en laag op sociale hiërarchie scoort. De formuleringen die wat meer ruimte laten om een verzoek te weigeren, worden op prijs gesteld omdat de vorm ervan samengaat met respect voor persoonlijke autonomie.

\subsection{DE NIET-CULTUURGEBONDEN PERCEPTIE VAN IMPERATIEVEN}

De gemiddelde taalgebruiker zal niet snel naar zijn cultuur wijzen om te verklaren waarom hij iets beleefd of onbeleefd vindt. Sterker nog: misschien weet hij zelfs niet hoe hiërarchisch en collectief zijn cultuur is ten opzichte van andere culturen. Vanuit zijn perspectief is vooral de situatie van belang waarin de boodschap wordt uitgesproken.

De aanpak die beschreven staat in de bundel Imperative Turns at Talk onder redactie van Sorjonen et al., gaat ervan uit dat imperatieven niet langer gezien worden als de minst beleefde vorm. Sorjonen et al. opteren ervoor om imperatieven niet als cultuurgebonden vormen te analyseren maar als 'onderdelen' van de hele situatie waarin het gesprek plaatsvindt. Wat in deze aanpak de grootste rol speelt, is de volgorde van activiteiten in een situatie waar imperatieven voor een effectieve en een vlotte overgang van de ene handeling naar de andere kunnen zorgen. Dit levert uiteindelijk voordelen op voor alle betrokken partijen (Rossi 103-104). Het gaat er dus niet om wat de vorm zelf communiceert, maar om hoe die wordt gebruikt in de communicatie (Sorjonen et al. 15). Volgens Mondada (66) ligt de nadruk dus op gezamenlijke activiteiten. De beleefdheid van gebruikte vormen is geen prioriteit.

141) merken echter op dat dit een onjuiste generalisatie kan zijn, want dan moeten we aannemen dat culturen in het Verre Oosten een nog directere communicatiestijl hebben dan Slavische culturen wat bijvoorbeeld niet voor Japan geldt. 


\section{RESULTATEN VAN DE ENQUÊTE}

De enquête ${ }^{10}$ bevatte in totaal 20 zinnen die allemaal in een context staan. De deelnemers moesten ze op beleefdheid beoordelen op een schaal van 1 tot 6 , waarbij 1 zeer onbeleefd betekent en 6 zeer beleefd. Alle zinnen komen uit informele corpusgesprekken, de relatie tussen de sprekers is (vrij) nauw ( $\mathrm{P}=$ laag, $\mathrm{D}=$ laag) en de gevraagde handelingen kosten vrij weinig moeite $(\mathrm{R}=$ laag). Van de 20 zinnen, bevatten 12 zinnen een variant van de imperatief: een kale imperatief, een versterkte of verzachte imperatief. Zo'n groot aantal imperatieve zinnen hangt samen met de vrij grote variatie aan imperatieven in het Pools. Van de 12 zinnen kwamen 10 zinnen voor in beide taalversies van de enquête: een zo letterlijk mogelijke vertaling en dezelfde context. De overige twee zinnen bevatten vormen die zich niet letterlijk laten vertalen naar de andere taal. In het Nederlands kan bijv. een kale infinitief worden gebruikt ('Doorlopen!'), maar de Polen gebruiken die infinitief samen met prosze, 'alstublieft'. Bij de vertaling zouden we dus twee verschillende constructies krijgen die anders aangevoeld kunnen worden. Bij elke zin moesten de deelnemers naast de beoordeling ook aangeven hoe ze deze zin zouden benoemen: een bevel, een eis, een opdracht, een verzoek, een suggestie of een hint. Uit de antwoorden van 129 deelnemers uit Polen en 169 uit Nederland kwamen de volgende resultaten (Tabel 1).

Tabel 1. Gemiddelde resultaten. Hoe hoger beoordeeld, des te beleefder een taalhandeling is.

\begin{tabular}{lcc}
\hline & $\begin{array}{c}\text { Nederlandse deelnemers } \\
\mathbf{N}=\mathbf{1 6 9}\end{array}$ & $\begin{array}{c}\text { Poolse deelnemers } \\
\mathbf{N}=\mathbf{1 2 9}\end{array}$ \\
\hline Gemiddelde alle zinnen & 3,888 & 3,913 \\
\hline Gemiddelde directe strategieën & 3,799 & 3,783 \\
Gemiddelde indirecte strategieën & 4,237 & 4,236 \\
& & \\
Gemiddelde imperatieven & 3,818 & 3,667 \\
Kale imperatieven en infinitief & 3,428 & 3,380 \\
Verzachte imperatieven & 4,365 & 4,607 \\
Versterkte imperatieven & 3,429 & 3,087 \\
\hline
\end{tabular}

${ }^{10}$ Voor meer informatie over de opbouw van de enquête, afname en vertaalproblemen zie Wiercińska. 
Uit de bovenstaande gegevens blijkt dat het gemiddelde van alle beoordeelde zinnen en ook de scores voor directe en indirecte ${ }^{11}$ strategieën in beide landen eigenlijk niet veel van elkaar afwijken. Bij nader inzien zit er echter een klein verschil in de perceptie van de imperatieven. Ten eerste geven de Nederlandse respondenten gemiddeld wat hogere scores. Het is dus niet zo dat Polen over het algemeen toleranter staan tegenover imperatieven, tenminste in de informele situaties van het pilot-onderzoek. De eerste hypothese (Polen staan over het algemeen toleranter tegenover imperatieven dan Nederlanders) wordt dus niet bevestigd. Als we kijken hoe vaak imperatieven gebruikt worden in informele gesprekken in Polen, is het opmerkelijk dat juist deze zinnen zo laag scoren op beleefdheid. Blijkbaar zit er dus een discrepantie tussen hoe we zinnen beoordelen op beleefdheid en wat we tolereren van mensen uit onze naaste omgeving.

Kale en versterkte imperatieven scoren onder Nederlanders bijna even hoog wat impliceert dat kale imperatieven in feite versterkt overkomen. De Poolse deelnemers beoordelen kale imperatieven daarentegen als beleefder dan versterkte imperatieven. In Nederland worden beide soorten imperatieven positiever beoordeeld dan in Polen en wat opvalt, is dat Nederlanders met name de versterkte imperatieven hoger hebben beoordeeld dan Polen. Het betekent echter niet automatisch dat Nederlanders deze vormen beleefd vinden. Ze vinden ze alleen een stukje minder onbeleefd aangezien deze zinnen alsnog lager scoren dan het gemiddelde van alle beoordeelde enquêtezinnen. Hier staat een voorbeeld van twee enquête-zinnen met de scores ten opzichte van het gemiddelde van de desbetreffende taalgroep.

(1) CONTEXT: Een vriend verstaat je niet en zegt:

NL: Praat toch duidelijker. $(-1,03)$

PL: Weź mów wyraźnie. $(-1,27)$

(2) CONTEXT: Je hebt een voordelige prijs uitonderhandeld. Je vertelt dit aan een vriend en hij zegt:

NL: Regel daar dan iets voor mij. $(-0,79)$

PL: To weź mi tam załatw. $(-1,14)$

Er is echter één uitzondering. In (3) schijnen de omstandigheden de doorslag te hebben gegeven, vooral bij de Nederlandse respondenten. Als het

\footnotetext{
${ }^{11}$ Behalve imperatieven omvatten de directe strategieën o.a. ook het gebruik van moeten (kaal, versterkt of verzacht). De indirecte strategieën omvatten o.a. vraagvormen, suggesties en onpersoonlijke constructies. Het verschil tussen beide soorten strategieën zit hem in hoe dwingend ze zijn. De directe strategieën geven nauwelijks ruimte voor eventuele weigering en de indirecte strategieën laten de toehoorder beslissen of hij een verzoek inwilligt of niet.
} 
waait, dan krijgen we daar allemaal last van. Het is dus in ons belang dat iemand de deur sluit. Het zou ook te maken kunnen hebben met de gangbaarheid van het Nederlandse 'kijk'.

(3) Het waait en jouw vader zegt:

NL: Sluit de deur want kijk: het waait. $(+0,32)$

PL: Zamykaj, bo patrz, wiatr jest. $(-0,01)$

Zinnen waarin imperatieven worden verzacht, scoren bovengemiddeld. Binnen deze categorie scoren die zinnen het hoogst waarin de imperatief wordt verzacht op logisch niveau, door bijvoorbeeld een voordeel te noemen voor de gesprekspartner (5) of wanneer de zender aangeeft zelf ook moeite te willen doen (4).

(4) CONTEXT: Jouw moeder wil helpen met koken en zegt:

NL: Laat me ten minste de aardappelen schillen zodat ik ook iets te doen heb. $(+0,92)$

PL: Daj mi chociaż ziemniaki obrać, żebym też miała coś do zrobienia. $(+0,98)$

(5) CONTEXT: Een vriendin heeft een exotisch biertje besteld en zegt:

NL: Proef het, misschien is het later niet meer mogelijk. $(+0,38)$

PL: Spróbuj, może nie będzie okazji. $(+0,98)$

Hoewel verzachte imperatieven de meest beleefde imperatieven zijn, blijkt uit Tabel 1 dat met name Poolse respondenten deze een stuk hoger hebben beoordeeld dan versterkte imperatieven. Het verschil is 1,57 in Polen en 0,936 in Nederland. De versterking of verzachting van een imperatief beïnvloedt de perceptie dus sterker in het Pools dan in het Nederlands. De tweede hypothese (De versterkte of verzachte vorm heeft meer invloed op de acceptatie van de imperatief in Nederland dan in Polen) wordt dus ook niet bevestigd.

Wat de laatste hypothese betreft (Polen ervaren imperatieven als minder dwingend), bestaat er een verband tussen de score en het percentage deelnemers die de zin in kwestie classificeert als een directief dat niet zo dwingend overkomt (dus als verzoek, suggestie of hint). Als we alleen naar de imperatieven kijken, dan zouden we verwachten dat ze grotendeels als bevelen of eisen worden gezien (cf. Vismans). Beide groepen respondenten benoemden deze zinnen echter vaak als verzoek of suggestie. Hoe zachter een imperatief is, hoe meer deelnemers uit beide landen zo'n vorm als minder dwingend 
zien. Zelfs versterkte imperatieven kunnen als minder dwingende directieven overkomen. Zin (5) wordt door $44 \%$ van de Nederlandse respondenten gelezen als suggestie en door $30 \%$ als verzoek. $72 \%$ van de Poolse respondenten heeft dezelfde zin gelezen als suggestie. Zin (4) wordt door $64 \%$ van de Nederlandse respondenten en $65 \%$ van de Poolse respondenten gelezen als suggestie. Zin (3) wordt daarentegen door $48 \%$ van de Nederlandse respondenten en $44 \%$ van de Poolse respondenten als opdracht gezien, maar zelfs daar is er een kleine groep respondenten uit elk land die hem als hint ziet (NL: 4\%, PL: 6\%).

In de overige zinnen met imperatieven zijn er bij nader inzien geen grote verschillen als we naar een ruimere verdeling kijken tussen dwingendere directieven (bevel, eis en opdracht) en minder dwingende directieven (verzoek, suggestie en hint). Uit de cijfers blijkt dat Polen imperatieven niet als dwingender ervaren dan Nederlanders. Als we de begrippen echter afzonderlijk bekijken, dan valt het op dat de Nederlandse respondenten meer de neiging hebben om een imperatieve constructie als een bevel te zien, terwijl de Poolse respondenten het eerder als een eis zien. Dit is het geval bij zinnen (1) en (2). Zin (1) wordt bijv. door $20 \%$ van de Nederlandse respondenten en $14 \%$ van de Poolse respondenten gezien als bevel. De Poolse respondenten kozen vaker voor eis (25\%). 11\% van de Nederlandse respondenten ziet zin (2) als bevel en $14 \%$ als eis. Bij de Poolse respondenten is dat respectievelijk 6\% en 29\%. De hoge score voor bevel onder de Nederlandse respondenten zou kunnen betekenen dat ze deze vormen interpreteren als dreigender voor hun persoonlijke autonomie, aangezien een bevel vooral te maken heeft met machtsafstand.

\section{CONCLUSIES}

Uit de enquête blijkt dat de respondenten uit beide landen imperatieve vormen op een gelijke manier beoordelen in die zin dat de imperatieven in beide versies van de enquête als hele groep onder het gemiddelde van alle beoordeelde zinnen scoren en dat verzachte imperatieven hoger scoren dan kale en versterkte imperatieven. Uit het onderzoek blijkt ook dat de Nederlandse respondenten de zinnen met imperatieven een klein beetje beleefder vonden. De overige hypotheses zijn ook niet bevestigd, omdat de versterking of verzachting van een imperatief meer doorslag gaf bij de beoordelingen van de Poolse respondenten. Het is ook niet zo dat Polen imperatieven over het algemeen als minder dwingend beschouwen. 
Dit resultaat is uiteraard beperkt tot één specifieke context. De omstandigheden van het gesprek waren informeel en de relatie tussen de sprekers was (vrij) nauw wat impliceert dat er geen afstand of machtsverhouding is tussen de sprekers $(\mathrm{D}=$ laag, $\mathrm{P}=$ laag). De handelingen die gevraagd waren, kostten ook niet veel moeite $(\mathrm{R}=\mathrm{laag})$. De vraag is of we een vergelijkbaar resultaat zouden krijgen als er variatie kwam in deze drie parameters, wat een denkrichting is voor verdere studie.

De volgende kwestie die nog verdieping vraagt, is waarom Polen zoveel imperatieven gebruiken in de dagelijkse communicatie terwijl, zoals uit deze pilot-studie blijkt, ze deze vormen niet beleefd vinden. De vraag is of het misschien, net zoals in het Chinees of het Russisch, te maken heeft met de verwachtingen die de Polen van de communicatie hebben: zouden ze dan meer belang hechten aan effectiviteit dan aan beleefdheid? Dat de deelnemers imperatieven negatief hebben beoordeeld kan ook te maken hebben met hoe assertief ze zichzelf vinden. Daar ging de pilot-enquête echter niet op in. Hoe assertiever de taalgebruiker denkt te zijn, hoe meer hij geneigd kan zijn om de verzoeken af te wijzen die hij niet beleefd geformuleerd vindt. Hier zou het interessant zijn om te kijken wat er na zo'n verzoek zou gebeuren. Gaat hij zo'n handeling uitvoeren? En zo ja: moppert hij dan nog over de toon? Of misschien weigert hij direct. Als de handeling wel (al dan niet met tegenzin) uitgevoerd wordt, dan zou het kunnen betekenen dat de effectiviteit toch de doorslag geeft.

\section{BIBLIOGRAFIE}

Beebe, Leslie M., en Martha Clark Cummings. "Natural Speech Act Data versus Written Questionnaire Data: How Data Collection Method Affects Speech Act Performance". Speech Act Across Cultures: Challenges to Communication in a Second Language, red. Susan Gass en Joyce Neu, Mouton de Gruyter, 1996, pp. 65-86.

Bolden, Galina. "Requests for Here-and-now Actions in Russian Conversations." Imperative Turns at Talk: The Design of Directives in Action, red. Marja-Leena Sorjonen, Liisa Raevaara, Elizabeth Couper-Kuhlen, John Benjamins Publishing Company, 2017, pp. 175-211.

Brown, Penelope, en Stephen Levinson. Politeness: Some Universals in Language Usage. Cambridge University Press, 2011 (1978).

Brown, Roger, en Albert Gilman, "Politeness Theory and Shakespeare's Four Major Tragedies." Language in Society, vol. 18, 1989, nr. 2, pp. 159-212.

Chen, Rong, Lin He en Chunmei Hu. "Chinese Requests: In Comparison to American and Japanese Requests and with Reference to the 'East-West Divide'". Journal of Pragmatics, vol. 55,2013 , pp. 140-161. 
Cyluk, Agnieszka. "Discourse Completion Task. Its Validity and Reliability in Research Projects on Speech Acts". Anglica. An International Journal of English Studies, vol. 22, nr. 2, 2013, pp. 101-112.

Czechowska, Anna. "O sposobach wyrażania prośby w języku polskim (na przykładzie wypowiedzi cudzoziemców)". Poradnik Językowy, vol. 4, 2005, pp. 29-42.

"De Technoloog: Smart speakers zijn smart listeners". 9.05.2018. Podcast van BNR Nieuwsradio, www.bnr.nl/podcast/de-technoloog/10343772/smart-speakers-zijn-smart-listeners. Geraadpleegd op 30.01.2019.

Doughty, Steve. "Why a Pole's Politeness Can Be Lost in Translation". MailOnline. 14 februari 2012, www.dailymail.co.uk/news/article-2100727/Why-Poles-politeness-lost-translation.html. Geraadpleegd op 30.01.2019.

Hofstede, Gert. Kultury i organizacje. Zaprogramowanie umystu [Cultures and Organizations: Software of the Mind]. Polskie Wydawnictwo Ekonomiczne, 2000.

Lee, Cynthia. "A Cross-Linguistic Study on the Linguistic Expressions of Cantonese and English Requests". Pragmatics, vol. 15, nr. 4, 2005, pp. 491-515.

Lee-Wong, Song Mei. "Imperatives in Requests: Direct or Impolite. Observations from Chinese". Pragmatics, vol. 4, nr. 4, 1994, pp. 491-515.

Lubecka, Anna. Requests, Invitations, Apologies and Compliments in American English and Polish. A Cross-cultural Communication Perspective. Kraków, Księgarnia Akademicka, 2000.

Łaziński, Marek. "Polacy na tle innych systemów grzeczności”. Jak zwracaja się do siebie Europejczycy, red. Małgorzata Marcjanik, Wydział Dziennikarstwa i Nauk Politycznych UW, 2013, pp. 15-32.

Mandelbaum, Jenny. "How to Do Things with Requests: Request Sequences at the Family Dinner Table". Requesting in Social Interaction, red. Paul Drew en Elizabet Couper-Kuhlen, John Benjamins Publishing Company, 2014, pp. 215-241.

Marcjanik, Małgorzata. Polska grzeczność językowa. Kielce, Wyższa Szkoła Pedagogiczna im. Jana Kochanowskiego, 1997.

Marcjanik, Małgorzata. "Przez grzeczność na skróty. O nonszalancji zachowań młodego pokolenia”. Retoryka codzienności. Zwyczaje językowe wspótczesnych Polaków, red. Małgorzata Marcjanik, Warszawa, Wydawnictwo Trio, 2006, pp. 230-238.

Mondada, Lorenza. "Precision Timing and Times Embeddedness of Imperatives in Embodied Courses of Action. Examples from French." Imperative Turns at Talk: The Design of Directives in Action, red. Marja-Leena Sorjonen, Liisa Raevaara, Elizabeth CouperKuhlen, John Benjamins Publishing Company, 2017, pp. 65-101.

Mulken, Margot van. "Politeness Markers in French and Dutch Requests". Language Sciences, vol. 18, nr. 3-4, 1996, pp. 698-702.

Ochs, Keenan. "The Universality of Conversational Postulates". Language in Society, vol. 5, 1987, pp. 67-80.

Ogiermann, Eva. "Politeness and Indirectness across Cultures: A comparison of English, German, Polish and Russian Requests". Journal of Politeness Research, vol. 5, nr. 2, 2009, pp. 189-216.

Pęzik, Piotr. "Spokes: A Search and Exploration Service for Conversational Corpus Data". Selected Papers from the CLARIN 2014 Conference, October 24-25, 2014, Soesterberg, The Netherlands, Linköping University Electronic Press, 2015, pp. 99-109. 
Pisarek, Larysa. Recevye Dejstvija i ich Realizacija v Russkom Jazyke v Sopostavlenii s Pol'skom. Wydawnictwo Uniwersytetu Wrocławskiego, 1995.

Rossi, Giovanni. "Secondary and Deciant Uses of the Imperative for Requesting in Italian." Imperative Turns at Talk: The Design of Directives in Action, red. Marja-Leena Sorjonen, Liisa Raevaara, Elizabeth Couper-Kuhlen, John Benjamins Publishing Company, 2017, pp. 103-137.

Imperative Turns at Talk: The Design of Directives in Action, red. Marja-Leena Sorjonen, Liisa Raevaara, Elizabeth Couper-Kuhlen, John Benjamins Publishing Company, 2017.

Vismans, Roel. "Modal Particles in Dutch Directives. A Study in Functional Grammar", PhD thesis, Amsterdam, Vrije Universiteit, 1994.

Wiercińska, Katarzyna. "Diminutief als beleefdheidsstrategie: Een vergelijking tussen Nederland en Vlaanderen". Roczniki Humanistyczne, vol. 64, z. 5, 2016, pp. 125-137.

Wiercińska, Katarzyna. "Op zoek naar perceptieverschillen bij directief taalgebruik in het Pools en in het Nederlands. Een onderzoeksvoorstel”. Germanica Pragensia, vol. 4, 2018, pp. 169-178.

Wierzbicka, Anna. "Different Cultures, Different Languages, Different Speech Acts: Polish vs. English". Journal of Pragmatics, vol. 9, nr 1, 1985, pp. 145-178.

Wijst, Per van der. "The Perception of Politeness in Dutch and French Indirect Requests". Text, vol. 15, nr. 4, 1995, pp. 477-501.

Zinken, Jörg, en Arnulf Depperman. "A Cline of Visible Commitment in the Situated Design of Imperative Turns. Evidence from German and Polish." Imperative Turns at Talk: The Design of Directives in Action, red. Marja-Leena Sorjonen, Liisa Raevaara, Elizabeth Couper-Kuhlen, John Benjamins Publishing Company, 2017, pp. 27-63.

Zinken, Jörg, en Eva Ogiermann. "Responsibility and Action. Invariants and Diversity in Requests for Objects in British English and Polish Interaction". Research on Language and Social Interaction, vol. 46, nr. 3, 2013, pp. 256-276.

\section{KTO JEST BARDZIEJ TOLERANCYJNY? \\ PERCEPCJA TRYBU ROZKAZUJĄCEGO W JĘZYKU POLSKIM I NIDERLANDZKIM W NIEFORMALNYM KONTEKŚCIE}

\section{Streszczenie}

Niniejszy artykuł skupia się na percepcji form trybu rozkazującego u rodzimych użytkowników języka polskiego i niderlandzkiego w spontanicznych konwersacjach i podsumowuje wyniki pilotażowego badania standardów grzecznościowych w Polsce i Holandii. Z uwagi na fakt, że użycie trybu rozkazującego $\mathrm{w}$ obu językach różni się pod względem ilościowym i jakościowym, można przyjąć, że również i percepcja tego rodzaju form może się różnić u użytkowników obu języków. Za pomocą ankiety, polegającej m.in. na ocenie wybranych wypowiedzi pod względem grzeczności, podjęto próbę zbadania, za jak uprzejme respondenci uważają formy trybu rozkazującego oraz jak na ich ocenę wpływa kontekst wypowiedzi.

Słowa kluczowe: język tryb rozkazujący; standardy grzecznościowe; percepcja; język polski; język niderlandzki. 


\section{WHO IS MORE TOLERANT? \\ THE PERCEPTION OF IMPERATIVES IN POLISH AND IN DUTCH \\ IN AN INFORMAL CONTEXT}

$\mathrm{Sum}$ mary

This contribution focuses on the perception of the imperative forms in spontaneous informal conversations among native speakers of Polish and Dutch, and reports on a pilot survey of standards of politeness. Since imperatives in Polish and Dutch are used qualitatively and quantitatively in a different way, we can assume that their perception is also different for native speakers of both languages. Using a survey consisting of, among other things, an assessment task, an attempt was made to investigate how polite the respondents think the imperative forms are, and how their assessment is influenced by the context of the utterance.

Key words: imperative; standards of politeness; perception; Polish; Dutch. 